\title{
Pengaruh Lari Zig Zag dan Side Jump Sprint terhadap Peningkatan Power Pemain Sepak Bola
}

\author{
Zulfikar H.Wada', Mufa Wibowo ${ }^{2}$ \\ 1. Universitas Aisyiyah Yogyakarta, email : zulfikarwada7@gmail.com \\ 2. Universitas Airlangga Surabaya, email : mufawibowo@ymail.com
}

\begin{abstract}
Abstrak. Prevalensi terjadinya penurunan power pada otot hamstring menurut American football > 41\%, sedangkan di Australian Rules Football terjadi penurunan power hamstring dengan presentase $16 \%$ yang angka kejadiannya pada urutan ketiga setelah cedera lutut dan ankle, oleh karena itu perluya peningkatan power otot tungkai karena mempunyai pengaruh yang sangat penting terhadap performa tim untuk mencapai prestasi sepak bola yang lebih baik. Tujuan penelitian untuk mengetahui perbedaan pengaruh lari zig zag dengan side jump sprint terhadap peningkatan power otot tungkai pada pemain sepak bola. Metode penelitian menggunakan desain quasi eksperimental. Sampelnya yaitu Pemain bola di lapangan Nogotirto Yogyakarta yang berusia 17-22 tahun, pengambilan sampel dengan tehnik total sampling, dengan kriteria inklusi dan eksklusi didapatkan 16 orang dan dibagi 2 kelompok sehingga masing-masing 8 orang. Kelompok intervensi 1 dengan lari zig zag dan kelompok intervensi II dengan side jump sprint yang dilakukan selama 4 minggu dengan frekuensi latihan 3 kali seminggu,kemudian diukur dengan vertical jump test. Hasil Uji Paired Sample T-test pada hipotesis I dan II diperoleh nilai $p: 0,000(p<0,05)$, dan uji beda menggunakan Indevendent Sample T-test diperoleh nilai $p: 0,633(p>0,005)$. Dapat disimpulkan Tidak ada perbedaan pengaruh latihan lari zig zag dengan latihan side jump sprint terhadap peningkatan power otot tungkai pada pemain sepak bola.
\end{abstract}

Kata Kunci : power, zig zag run, side jump sprint, vertical jump

\section{The Influence of Zig Zag Running and Side Jump Sprint on Increasing the Power of Football Players}

\begin{abstract}
The prevalence of decreasing power in the hamstring muscles according to American football $>$ $41 \%$, while in Australian Rules Football there is a decrease in power hamstring with a percentage of $16 \%$ which occurs in third place after knee and ankle injuries, therefore the need to increase leg muscle power because it has a very important influence on team performance to achieve better football performance. The purpose of this study was to determine the differences in the effect of zig zag running with side jump sprint on increasing leg muscle power in football players. The research method use quasi experimental design. The sample is football players in Yogyakarta Nogotirto field aged 17-22 years, taking the sampling with total sampling techniques, with inclusion and exclusion criteria found 16 people and divided into 2 groups so that each 8 people. Intervention group 1 with zig zag running and intervention group II with side jump sprint conducted for 4 weeks with exercise frequency 3 times a week, then measured by vertical jump test. The results of the Paired Sample T-test in hypotheses I and II obtained p values: $0,000(p<0.05)$, and different tests using the Independent Sample T test obtained p values: 0.633 ( $p>0.005$ ). It can be concluded that there is no difference in the effect of zig zag running exercises with side jump sprint exercises on increasing leg muscle power in football players.
\end{abstract}

Keywords: power, zig zag run, side jump sprint, vertical jumps 


\section{Pendahuluan}

Dalam sepakbola permasalahan yang sering di alami oleh pemain sepak bola adalah penurunan kondisi fisik dan belum sempurnanya penguasaan tehnik sehingga berdampak terhadap prestasi dari pemain. Daya ledak adalah salah satu unsur kondisi fisik yang dibutuhkan untuk hampir semua cabang olahraga termasuk didalamnya permainan sepak bola. Menurut Komarudin (2011), "kemampuan motorik yang menunjang terhadap pelaksanaan sepakbola sangatlah banyak, diantaranya kelincahan, kelentukan, kecepataan, dan kesimbangan".

Menurut Ebben (2014), Sekitar $12 \%$ sampai $15 \%$ atlit mengalami penurunan daya ledak pada otot hamstring yang penyebabnya yaitu karena latihan yang kurang atau latihan yang dilakukan tidak seimbang sehingga terjadi penurunan pada daya ledak namun, jika keseimbangan otot hamstring dan quadriceps bisa dijaga akan mempunyai peran untuk mencegah penurunan daya ledak pada otot hamstring. Kekuatan daya ledak dari otot ini dipengaruhi oleh faktor usia, jenis kelamin, berat badan, lalu kekuatan otot hamstring ini juga bertujuan menstabilkan lutut dan mencegah terjadinya cidera ACL dalam menjaga stabilitas sendi

Prevalensi terjadinya penurunan power pada otot hamstring menurut American football $>41 \%$, sedangkan di Australian Rules Football terjadi penurunan power hamstring dengan presentase $16 \%$ yang angka kejadiannya pada urutan ketiga setelah cedera lutut dan ankle (Rogan., 2013). Kemudian penelitian yang di lakukan oleh Tarmizit tahun (2016) di indonesia menjelaskan bahwa terjadi penurunan daya ledak saat melakukan shooting dengan presentase $>80 \%$ dari 20 orang atlet yang ditelitinya
Berdasarkan Data dari PSSI Kab. Sleman mempunyai 4 Divisi Sepak bola yang terdiri dari 88 klub Sepak bola yaitu Divisi Super ada 8 klub, Divisi Utama ada 21 klub, Divisi Satu ada 20 klub dan Divisi Dua ada 39 klub. Selama 1 tahun terakhir di kompetisi Sepak bola di Kab.Sleman, pada kompetisi Liga Sleman terakhir pada bulan Februari 2016 di Stadion Tridadi Sleman, dari 4 divisi tersebut, tim sepak bola yang belum pernah memenangkan kompetisi yaitu PS.Telaga Utama. Kemudian dari studi pendahuluan pada 4 klub sepak bola diatas dan total pemain yaitu PS.Telaga Utama 22 orang, PS.Tunas Muda 23 orang, PS.Perseta 20 orang, PS. Sardonoharjo 22 orang, totalnya kurang lebih 87 orang, didapatkan PS.Telaga Utama yang paling rendah dengan vertical jump test yaitu 30-40 cm,sedangkan untuk vertical jump test yang sempurna yaitu $70 \mathrm{~cm}$.

Minimnya prestasi olahraga dikarenakan pembinaan kondisi fisik yang belum baik dan belum terarah serta pelatihan fisik yang diberikan masih monoton dan ketika ada turnamen saja baru diadakan latihan sehingga banyak merasa malas dengan latihan yang diberikan,terutama bagi para pemain sepak bola yang baru bergabung dalam tim ini, yang akibatnya menurunya prestasi dan saat mengikuti pertandingan performa tim tidak maksimal dalam mencapai tujuan yang harapkan saat bertanding.

Sehingga diperlukan upaya seperti Latihan yang bertujuan untuk memperbaiki sistem serta fungsi fisiologis dan psikologis tubuh agar pada waktu melakukan aktivitas olahraga dapat mencapai penampilan optimal

Daya ledak menyangkut kekuatan dan kecepatan kontraksi otot yang dinamis dan eksplosif serta melibatkan pengeluaran kekuatan otot yang 
maksimal dalam waktu yang secepatcepatnya. Sehingga ada dua komponen yang sangat penting di dalam daya ledak, yaitu kekuatan otot dan kecepatan otot, maka daya ledak dapat dimanipulasi atau ditingkatkan dengan melalui meningkatkan kekuatan otot tanpa mengabaikan kecepatan otot atau sebaliknya dapat meningkatkan kecepatan otot tanpa mengabaikan kekuatan otot.

Latihan ini melibatkan otot-otot seperti otot-otot Otot tungkai bawah terdiri dari musculus tibialis, musculus ekstensor,talangus longus, musculus ekstensor digitorum longusand brevis,musculus fleksor hallucis longus, musculus soleus, musculus gastrocnemius, musculus ankle plantar fleksor, tendo akiles dan musculus ekstensor superior retinakulum (Andriyani dkk, 2014)

Menurut I Pt Gd Winartha (2015), Gerakan lari yang diberikan secara cepat akan membuat stres pada komponen otot tungkai sehingga otot tungkai akan mengalami adaptasi. Adaptasi otot yang utama yaitu hypertrophy, bertambahnya massa otot. Hypertrophy otot disebabkan bertambahnya diameter serabut otot, sedangkan jumlah serabut otot tampaknya tidak berpengaruh terhadap latihan biasa. Perkembangan hypertrophy berhubungan dengan terjaganya jumlah peningkatan jaringan protein aktin dan miosin yang mampu mengerut.

Selanjutnya, kekuatan otot bertambah melalui adaptasi sistem saraf yang memungkinkan subyek yang menggerakkan jumlah unit gerak yang membesar pada suatu waktu dari pelatihan yang diberikan serta karena bertambahnya serabut otot otomatis memperbanyak sel-sel otot, dimana didalamnya terdapat penambahan mitokondria. Maka pelatihan yang diberikan dapat menyebabkan adaptasi fisiologis terhadap otot berupa hypertrophy otot, hyperplasia otot, meningkatnya jumlah mitokondria, sehingga dapat meningkatkan kekuatan otot dan meningkat meningkatkan kecepatan. Selanjutnya peningkatan kekuatan pada tahap awal ini dapat terjadi pada orang terlatih setelah pemberian latihan selama 4 minggu

\section{Metode}

Metode yang digunakan Dalam Penelitian ini adalah Experimental design dengan rancangan randomized pre test and post test two group design, tujuananya untuk membandingkan perbedaan zigzag dan side jump sprint terhadap power tungkai pada pemain bola. Populasi yang diambil adalah semua pemain sepak bola PS.Telaga Utama, sample yang digunakan adalah semua pemain PS.Telaga Utama yang terdiri dari 16 orang .Penelitian ini menggunakan 2 kelompok dengan tehnik purposive sampling, kelompok intervensi 1 dengan lari zig zag dan kelompok intervensi 2 dengan side jump sprint kemudian untuk mengukur power dengan menggunakan vertical jump test.

Tempat penelitian ini dilakukan di lapangan Nogotirto, Godean, Kabupaten Sleman Yogyakarta. Penelitian ini dilaksanakan selama 4 minggu dengan frekuensi latihanya adalah 3 kali pertemuan dalam seminggu, yang bertujuan untuk memberikan kesempatan tubuh beradaptasi terhadap beban yang diberikan dalam pelatihan ini

Tehnik analisis data normalitas menggunakan shapiro wilk test, uji Homogenitas menggunakan levene's test, sedangkan uji hipotesis I dan II menggunakan paired sample t-test,dan uji Beda dengan Independen Sample t-test. 


\section{Hasil penelitian}

1. karakteristik umur sampel pada latihan lari zig zagn dan side jump sprint

Tabel 1. karakteristik umur sampel pada latihan lari zig zagn dan side jump sprint

\begin{tabular}{ccccc}
\hline & \multicolumn{2}{c}{ Kelompok } & \multicolumn{2}{c}{ Kelompok } \\
& \multicolumn{2}{c}{$\mathrm{I}(\mathrm{ZZ})$} & \multicolumn{2}{c}{ II(SJS) } \\
Usia & $\mathrm{n}$ & $\%$ & $\mathrm{n}$ & $\%$ \\
\hline $17-19$ & 1 & 12,5 & - & 0 \\
$20-22$ & 7 & 87,5 & 8 & 100 \\
& & & & \\
\hline Jumlah & 8 & 100 & 8 & 100 \\
\hline
\end{tabular}

Berdasarkan tabel 1 didapatkan hasil bahwa usia responden dalam penelitian ini berkisar antara 17-22 tahun. Pada kelompok I usia responden terbanyak adalah usia 22 tahun ( 4 orang) dan usia paling sedikit adalah usia 18 tahun (1 orang), sedangkan pada kelompok II usia responden terbanyak adalah usia 22 tahun ( 3 orang) dan usia paling sedikit adalah usia 21 tahun (2 orang).

2. karakteristik Indeks MassaTubuh sampel pada latihan lari zig zag dan side jump sprint

Tabel 2. Karakteristik Indeks Massa tubuh sampel pada latihan zig zag dan side jum sprint

\begin{tabular}{ccccc}
\hline & \multicolumn{2}{c}{ Kelompok } & \multicolumn{2}{c}{ Kelompok } \\
IMT & I(ZZ) & \multicolumn{2}{c}{ II } \\
\hline Underweight & - & - & - & - \\
Normal & 8 & 100 & 8 & 100 \\
Overweight & - & - & - & - \\
\hline Jumlah & 8 & 100 & 8 & 100 \\
\hline
\end{tabular}

Berdasarkan tabel 2 didapatkan hasil bahwa pada kelompok I nilai IMT Normal berjumlah (8 orang), sedangkan pada kelompok II nilai IMT nornal berjumlah (8 orang)

3. hasil sebelum dan sesudah dilakukan lari zig zag dan side jump sprint terhadap power otot tungkai pada pemain sepak bola

Tabel 3. hasil sebelum dan sesudah dilakukan lari zig zag dan side jump sprint terhadap power otot tungkai pada pemain sepak bola

\begin{tabular}{ccccc}
\hline \multirow{2}{*}{ NO } & \multicolumn{2}{c}{ KELOMPOK I } & \multicolumn{2}{c}{ KELOMPOK } \\
& \multicolumn{3}{c}{ II } \\
\cline { 2 - 5 } & PRE & POST & PRE & POST \\
\hline 1 & 51 & 53 & 35 & 37 \\
2 & 39 & 48 & 47 & 58 \\
3 & 45 & 53 & 35 & 42 \\
4 & 38 & 45 & 43 & 49 \\
5 & 40 & 47 & 43 & 50 \\
6 & 49 & 55 & 50 & 55 \\
7 & 50 & 57 & 42 & 50 \\
8 & 38 & 41 & 39 & 46 \\
\hline MEAN & 43,75 & 49,87 & 41,75 & 48,37 \\
SD & 5,650 & 5,488 & 5,311 & 6,738 \\
\hline
\end{tabular}

Berdasarkan tabel 3 didapatkan hasil bahwa pre-test power otot tungkai pada kelompok I dengan perlakuan lari zig zag diperoleh nilai rata-rata 43,75 dengan nilai tertinggi 51 nilai terendah 38 dan standar deviasi 5,650 sedangkan untuk post-test diperoleh nilai rata-rata 49,87 dengan nilai tertinggi 57 nilai terendah 41 dan standar deviasi 5,488. Kemudian hasil pre-test power otot tungkai pada kelompok II dengan perlakuan side jump sprint diperoleh nilai rata-rata 41,75 dengan nilai tertinggi 50 nilai terendah 35 dan standar deviasi 5,311 sedangkan untuk post-test diperoleh nilai rata-rata 48,37 dengan nilai tertinggi 58 nilai terendah 37 dan standar deviasi 6,738 .

4. Pengaruh latihan zig zag terhadap peningkatan power otot tungkai pada pemain sepak bola 
Tabel 4. hasil uji pengaruh latihan zig zag terhadap peningkatan power otot tungkai

\begin{tabular}{|c|c|c|c|c|c|}
\hline \multirow{2}{*}{$\begin{array}{c}\text { Keterangn } \\
\text { Post-post } \\
\text { vertical } \\
\text { jump }\end{array}$} & \multicolumn{2}{|c|}{$\begin{array}{c}\text { Kelompok I } \\
(\mathrm{ZZ})\end{array}$} & \multicolumn{2}{|c|}{$\begin{array}{c}\text { KelompokI } \\
\text { I (SJS) } \\
\end{array}$} & \multirow[b]{2}{*}{$p$} \\
\hline & Mean & $S D$ & Mean & $S D$ & \\
\hline $\begin{array}{c}\text { jump } \\
\text { kelompok I } \\
\text { dan II }\end{array}$ & 49,87 & 5,488 & 48,37 & 6,738 & 0,633 \\
\hline
\end{tabular}

Berdasarkan tabel 4. Dengan mengunakan uji Paired Sampel T-test pada kelompok I didapatkan hasil bahwa Selisih rerata nilai Vertical jump sebelum dan sesudah perlakuan pada kelompok Lari zig zag adalah 6,125 dengan simpangan baku 2,416 Hasil perhitungan paired samples $t$-test adalah $p=0,000(p<$ 0,05 artinya ada pengaruh lari zig zag pada pemain sepak bola untuk meningkatkan power otot tungkai

5. Pengaruh latihan side jump sprint terhadap peningkatan power otot tungkai pada pemain sepak bola

Tabel 5. hasil uji pengaruh latihan zig zag terhadap peningkatan power otot tungkai pada pemain sepak bola

\begin{tabular}{llll}
\hline Sampel & $\mathrm{N}$ & Mean \pm & $P$ \\
& & $S D$ & \\
\hline Kelompok & 8 & $-6,625 \pm$ & 0,000 \\
SJS & & 2,559 &
\end{tabular}

Berdasarkan tabel 5 Dengan mengunakan uji Paired Sampel T-test pada kelompok II didapatkan hasil bahwa Selisih rerata nilai Vertical jump sebelum dan sesudah perlakuan pada kelompok SJS adalah 6,625 dengan simpangan baku 2,559. Hasil perhitungan paired samples $t$-test adalah $p=0,000(p<$ $0,05)$ yang berarti ada pengaruh latihan side jump sprint pada pemain sepak bola untuk meningkatkan power otot tungkai 6. Perbedaan pengaruh latihan lari zigzag dan side jump sprint terhadap peningkatan power otot tungkai pada pemain sepak bola

Tabel 6. hasil uji Perbedaan pengaruh latihan lari zig-zag dan side jump sprint terhadap peningkatan power otot tungkai pada pemain sepak bola

\begin{tabular}{llll}
\hline Sampel & N & $\begin{array}{l}\text { Mean } \pm \\
\text { SD }\end{array}$ & $p$ \\
\hline Kelompok & 8 & $-6,125 \pm$ & 0,000 \\
Lari Zig-Zag & & 2,416 & \\
\hline
\end{tabular}

Berdasarkan tabel Dengan mengunakan uji Independent Samples Ttest untuk membandingkan nilai vertical jump sesudah perlakuan pada kelompok I dengan nilai rata rata 49,67 dengan simpangan baku 5,488 dan kelompok II dengan nilai rata-rata 48,37 dengan sipangan baku 6,738. Hasil perhitungan diperoleh nilai $p: 0,633(p>0,005)$ yang artinya tidak ada perbedaan pengaruh lari zig-zag dan side jump sprint terhadap peningkatan power otot tungkai pada pemain sepak bola

\section{Pembahasan}

Daya ledak menyangkut kekuatan dan kecepatan kontraksi otot yang dinamis dan eksplosif serta melibatkan pengeluaran kekuatan otot yang maksimal dalam waktu yang secepatcepatnya. Sehingga ada dua komponen yang sangat penting di dalam daya ledak, yaitu kekuatan otot dan kecepatan otot, maka daya ledak dapat dimanipulasi atau ditingkatkan dengan melalui meningkatkan kekuatan otot tanpa mengabaikan kecepatan otot atau sebaliknya dapat meningkatkan kecepatan otot tanpa mengabaikan kekuatan otot. Ada beberapa faktor pada penelitian ini yang mempengaruhi power yaitu Usia dan IMT

Hasil dari tabel sampel menurut usia yang peneliti dapatkan dari hasil penelitian ini adalah pada latihan lari zigzag lebih banyak responden dengan usia 
22 tahun yaitu 4 orang (50\%). Sedangkan pada latihan side jump sprint responden lebih banyak pada usia 22 tahun yaitu orang (40\%). Usia dari 17-22 tahun merupakan puncak umur yang baik untuk meningkatkan performa daya ledak otot.

Menurut Andriani LM (2014) Untuk mendapatkan peningkatan kemampuan yang baik, perlu diperhatikan faktor usia dalam memberikan pelatihan. Usia yang sesuai dan memiliki progresifitas yang baik adalah pada masa adolesensi. Masa adolesensi merupakan masa transisi dari masa remaja menjadi dewasa, dimana masa ini anak mampu melakukan gerakan kompleks dan terstruktur yang nantinya dapat memperbaiki prestasi individu itu sendiri ataupun prestasi bagi timnya

Menurut Rismana

Responden dalam penelitian ini berusia 18-23 tahun, dengan hasil uji analisa data menyatakan usia responden yang banyak mengalami peningkatan kekuatan otot adalah responden usia 18-19 tahun. Kekuatan otot mulai timbul sejak lahir sampai dewasa dan terus meningkat terutama pada usia 20 sampai 30 -an dan secara gradual menurun seiring dengan peningkatan usia.

Hasil dari tabel sampel menurut Masa Tubuh. IMT adalah perhitungan dari berat badan dan tinggi badan. Indeks Massa Tubuh pada latihan lari zig-zag yaitu kelompok I nilai IMT normal (8 orang), sedangkan pada kelompok II nilai IMT pada latihan Side Jump Sprint adalah nilai IMT nornal (8 orang) . Dalam permainan sepak bola gerakan sering yang dilakukan yaitu, seperti melompat, passing/mengumpan bola, heading /menyundul bola, sprint/lari dengan kecepatan tinggi, beradu lari, berbenturan dengan badan teman, menendang bola, dan yang lainnya sangat bergantung pada IMT
Menurut Kisner dan Colby (2007) Berat badan atau IMT yang berlebihan secara langsung akan mengurangi kecepatan, dimana berat badan yang berlebihan cenderung mengakibatkan muscle imbalance di bagian trunk juga adanya friksi jaringan lemak pada serabut otot sehingga kontraksi otot menjadi berkurang. Otot dalam berkontraksi dan menghasilkan tegangan memerlukan suatu tenaga atau kekuatan. Kekuatan mengarah kepada output tenaga dari kontraksi otot dan secara langsung berhubungan dengan sejumlah tension yang dihasilkan oleh kontraksi otot, sehingga meningkatkan kekuatan otot berupa level tension, hipertropi, dan recruitment serabut otot

Hasil penelitian dengan paired sampel T-test pada kelompok I didapatkan hasil bahwa Selisih rerata nilai Vertical jump sebelum dan sesudah perlakuan pada kelompok Lari zig zag adalah 6,125 dengan simpangan baku 2,416 Hasil perhitungan paired samples $t$ test adalah $p=0,000(p<0,05$ artinya ada pengaruh lari zig zag pada pemain sepak bola untuk meningkatkan power otot tungkai. Latihan ini lebih mengarahkan pada kemampuan kinerja otot-otot tungkai. Dapat dibuktikan dengan pelaksanaannya, seseorang dituntut untuk mampu membawa titik berat badan dengan berkelok melalui beberapa jalur tiang atau cones dan dalam waktu yang singkat. Dengan demikian seorang pemain yang melakukan latihan zig-zag run tentunya memperoleh kemampuan fisik, daya ledak dan kelincahan (Anto Sukamto, 2012).

Hal ini sesuai dengan penelitian oleh Yekti Lingga Dinata (2013). Dari hasil uji perbedaan yang dilakukan terhadap tes akhir (post-test) pada kelompok 1 dan 2, diperoleh nilai t sebesar $-4,256$ dengan nilai probabilitas sebesar $0,005 \quad(p<0,05)$, yang berarti ada perbedaan yang signifikan power otot 
tungkai hasil tes akhir (post-test) pada kedua kelompok.Sehingga hasil dari penelitian ini pada kelompok satu dengan latihan front cone hops mengalami peningkatan power otot tungkai sebesar $19,77 \%$ dan pada latihan zig-zag drill mengalami peningkatan power otot tungkai sebesar $80,94 \%$. Dapat disimpulkan bahwa zig zag drill lebih baik dalam meningkatkan daya ledak otot tungkai daripada front cone hops.

Hasil penelitian dengan paired sampel T-test pada kelompok II didapatkan hasil bahwa Selisih rerata nilai Vertical jump sebelum dan sesudah perlakuan pada kelompok Lari zig zag adalah 6,125 dengan simpangan baku 2,416 Hasil perhitungan paired samples $t$ test adalah $p=0,000(p<0,05$ artinya ada pengaruh lari zig zag pada pemain sepak bola untuk meningkatkan power otot tungkai.Hal sesuai dengan penelitian yang pernah dilakukan I Kadek Darmadi (2016), Dari hasil penelitian uji beda pada kelompok Side jump sprint didapatkan nilai $p=0.000(p<0.005)$ yang artinya ada perbedaan yang signifikan dari peningkatan daya ledak otot tungkai sebelum dan sesudah pelatihan Side jump sprint.Sehingga Menurut Marino (2102) Dilihat dari gerakannya, maka yang perlu ditingkatkan yaitu, power, kelincahan dan kecepatan. Jika latihan ini dilakukan secara berulang-ulang dapat meningkatkan power, kecepatan, kelincahan dan koordinasi gerakan.

$$
\text { Hasil penelitian dengan }
$$

indipendent sample T-test untuk membandingkan nilai vertical jump sesudah perlakuan pada kelompok I dengan nilai rata rata 49,67 dengan simpangan baku 5,488 dan kelompok II dengan nilai rata-rata 48,37 dengan sipangan baku 6,738 . Hasil perhitungan diperoleh nilai $p: 0,633(p>0,005)$ yang artinya tidak ada perbedaan pengaruh lari zig-zag dan side jump sprint terhadap peningkatan power otot tungkai pada pemain sepak bola .

Daya ledak menyangkut kekuatan dan kecepatan kontraksi otot yang dinamis dan eksplosif serta melibatkan pengeluaran kekuatan otot yang maksimal dalam waktu yang secepatcepatnya. Sehingga ada dua komponen yang sangat penting di dalam daya ledak, yaitu kekuatan otot dan kecepatan otot, maka daya ledak dapat dimanipulasi atau ditingkatkan dengan melalui meningkatkan kekuatan otot tanpa mengabaikan kecepatan otot atau sebaliknya dapat meningkatkan kecepatan otot tanpa mengabaikan kekuatan otot.

Latihan ini juga akan membentuk kemampuan unsur kecepatan dan kekuatan otot yang menjadi dasar terbentuknya daya ledak otot. Penerapan kedua metode latihan tersebut dapat memberikan hasil yang relatif sama terhadap peningkatan kemampuan lompat jauh tanpa awalan. Jenis-jenis latihan, khususnya latihan yang menggunakan beban dapat menimbulkan peningkatan yang besar dan cepat pada kekuatan otot. Peningkatan kekuatan pada tahap awal ini dapat terjadi pada orang terlatih setelah pemberian latihan selama 4 minggu (Eastern, 1998) dalam Rismana (2013).

\section{SIMPULAN}

Berdasarkan hasil penelitian dan pembahasan maka dapat diambil beberapa kesimpulan bahwa tidak ada perbedaan pengaruh latihan Lari zig zag dan latihan Side jump sprint terhadap peningkatan daya ledak otot tungkai pada pemain sepak bola,sehingga diharapkan club dapat menjadikan lari zig-zag dan side jump sprint sebagai salah satu intervensi untuk meningkatkan daya ledak tungkai pada pemain sepak bola, lalu untuk Peneliti selanjutnya dapat melakukan penelitian pada club sepak 
bola yang profesional dan mempunyai waktu intervensi yang lebih banyak lagi dan dapat melakukan penelitian sejenis ini dan dilakukan penelitian lebih lanjut berdasarkan faktor lainya, variabel yang yang berbeda, jumlah sampel yang lebih banyak dan tempat yang berbeda.

\section{DAFTAR PUSTAKA}

Aan sunjata. (2010). Pendidikan Jasmani Olahraga Dan Kesehatan Smp/Mts Kelas Vii. Jakarta, Pusat Pembukuan, Kementrian Pendidikan Nasional.

Abdurrahman. (2011). Perbandingan Kekuatan Otot Tungkai Antara Siswa Gemuk dan Kurus. Jurnal Olahraga.

American College of Sports Medicine, American Dietetic Association, and Dietitians of Canada. (2009). "Nutrition and athletic performance: joint position statement," Medicine \& Science in Sports \& Exercise, vol. 41 , no. 3 , pp. $709-731$.

c Anwar, Saiful. (2013). Survei Teknik Dasar Dan Kondisi Fisik Pada Siswa Sepakbola (SSB) SE Kabupaten Demak.

Andriani LM, Parwata IG, Arsani NL. (2014) Pengaruh Pelatihan 30 Second Box Drill dan 60 Second Box Drill terhadap Daya Ledak Otot Tungkai. e-journal Jurnal IKOR Universitas Pendidikan Ganesha Jurusan Ilmu Keolahragaan

Andriyani dkk. 2014.EJournal IKOR Universitas Pendidikan Ganesha Jurusan Ilmu Keolahragaan

Arikunto, S. (2010) .Prosedur Penelitian Suatu Pendekatan Praktik. Cetakan ke II. Edisi Revisi IV. PT. Rineka Cipta: Jakarta.

Berryman N, Maurel D, Bosquet L. (2010). Effect of plyometric vs. Dynamic weight training on the energy cost of running. J Strength Cond Res;24:1818-25.

Bonnette R, Spanoiol F, Melrose D, Ocker L, Dyer R. (2011). The effect ofagility, plyometric, and sprint training on the speed endurance and powerof high school soccer players. $J$ Strength Cond Res 25(Suppl. 1):S119.

Bompa, T.O. (2005) Power Training For Sport, Plyometric For Maximum Power Development. Canada: Mosaic Press

Ebben, W. P. (n.d.). (2013). Using Squat Repetition Maximum Testing to Determine Hamstring Resistance Training Exrecise Loads. Proquest Public Health.

Efva Nonalisa. (2013). Landasan Konseptual Perencanaan Dan Perancangan Sekolah Sepak Bola Di Yogyakarta.

Eri Pratiknyo Dwi Kusworo. (2010). Tes Pengukuran dan Evaluasi Olahraga. Semarang: Widya Karya

Febriadi . F. (2016). Perbedaan Pengaruh Latihan Single Leg Speed Hop Dengan Latihan Knee Tuck Jump Terhadap Peningkatan Daya Ledak Otot Tungkai Pada Pemain Futsal. Yogyakarta.

Giriwijoyo,S dan Sidik, D.Z. (2012). Ilmu Kesehatan Olahraga. Bandung: Remaja Rosdakarya. 
Hasanah. (2013). Pengaruh latihan pliometrik depth jumpdan jump to box terhadap power otot tungkai pada atlet bola voli klub tugu muda kota semarang.

I Ketut Wiradana. (2016) Pengaruh Pelatihan Side Jump Sprint Dan Dodging Run Terhadap Kecepatan Siswa Ekstrakurikuler Sepak Bola Di Smp Negeri 4 Kuta Selatan Tahun Pelajaran 2015/2016. Journal Ilmu Keolahragaan Universitas Pendidikan Ganesha

I Pt Gd Winartha (2015) Pengaruh Pelatihan Side Jump Sprint Terhadap Kecepatan Dan Kelincahan Pada Siswa Peserta Ekstrakurikuler Pencak Silat Sma Negeri 1 Abiansemal Tahun Pelajaran 2014/2015. journal IKOR Universita Pendidikan Ganesha

I Kadek Darmadi (2016) Pengaruh Pelatihan Quick Leap Dan Side Jump Sprint Terhadap Peningkatan Daya Ledak Otot Tungkai. Journal IKOR Universitas Pendidikan Ganesha

Kanca, I Nyonman. (2010). Metode Penelitian Pengajaran Pendidikan Jasmani Dan Olahraga. Singaraja: Undiksha.

Komarudin. (2011). Dasar Gerak Sepak Bola. Yogyakarta: FIK UNY.

Lesmana, Syahmirza Indra. (2012). Perbedaan Pengaruh Metode Latihan Beban terhadap Kekuatan dan Daya Tahan Otot Biceps Brachialis ditinjau dari Perbedaan Gender (Studi Komparasi Pemberian Latihan Beban Metode Delorme dan Metode Oxford pada Mahasiswa Fakultas Ilmu Kesehatan dan Fisioterapi). Jakarta.
Lhaksana, J. (2011). Taktik \& Strategi Futsal Modern. Jakarta: Penebar Swadaya Group.

Marino. (2010). Artikel Ilmiah. Pengaruh Model Latihan Dan Koordinasi Mata- Kaki Terhadap Kemampuan Menggiring Bola Pada Permainan Sepak Bola. Universitas Sebelas Maret, Surakarta.

Mastikayasa Kadek I. (2012). Artikel Ilmiah. Pengaruh Pelatihan Plaiometric Side Jump Sprint Terhadap Kecepatan Dan Kekuatan Otot Tungkai. FORKES Universitas Pendidikan Ganesha, Singaraja.

Muhammad Muhyi Faruq. (2008). Meningkatkan Kebugaran Tubuh Melalui Permainan \& Olahraga Sepak Bola. Jakarta: PT. Gramedia Widi asarana Indonesia.

Muhajir. (2007). Pendidikan Jasmani Olahraga dan Kesehatan. Jilid1. Jakarta: Erlangga.

Muh. Ali Masyar, Dwi Narhayu. (2010). Pendidikan jasmani Olahraga dan Kesehatan untuk SMP Kelas IX, Pusat Perbukuan Kementrian Pendidikan Nasional, Jakarta.

Nurhasan. (2011). Kebugaran Jasmani. Abil Pustaka. Gresik, Jawa Timur.

Rismana, E.A. (2013). Pengaruh Pemberian Delorme Terhadap Kekuatan Otot Quadriceps Femoris Pada Pemain Futsal

Rogan S, Wust D, Schwitter T et al (2013). Static stretching of the hamstring muscle for injury prevention in football codes: a 
systematic review. Asian J Sports Med 4:1-9.

Rusly, A.W. (2007). "Kontribusi Daya Ledak (Power) Otot Tungkai Pada Kemampuan Menendang Bola (Shooting) Kesasaran". Skripsi Tidak Diterbitkan. Surabaya. Universitas Negeri Surabaya.

Sedano S, Marín PJ, Cuadrado G, Redondo JC .(2013). Concurrent training in elite male runners: the influence of strength versus muscular endurance trainingon performance outcomes. J Strength Cond Res 2013;27:2433-43.

Sugondo S. (2006). Obesitas. In : Sudoyo A.W, dkk (eds). Buku Ajar Ilmu Penyakit Dalam Jilid III Edisi IV. Jakarta: FKUI, hal : 1919-1925.

Sukadiyanto, (2005). Pengantar Teori dan metodologi Melatih Fisik. Yogyakarta: Universitas Negeri Yogyakarta.

Schmottlach, Neil. (2010). Physical Education Activity Handbook. San Fransisco : Benjamin Cummings.
Tarmizi,Ahmad (2015). Perbedaan Pengaruh Metode latihan Shooting After A Dribble dengan latihan Shootingafter A Centering Pass terhadap hasil kemampuan Shooting pemain sepak bola sejati pratama medan Johor Tahun 2015.

Wilmore, J.H., Costill D.L., Kenney. W. L. (2008). Physiology of Sport and Exercise 4th edition. United States: Human Kinetics, 13-14.

Widnyana, M. Nurmawan, P.S. Tianing, N.W. (2014). Plyometric Exercise Single Leg Speed Hop Dan Double Leg Speed Hop Meningkatkan Daya Ledak Otot Tungkai Pada Pemain Sepak Bola Physio Team Fakultas Kedokteran Universitas Udayana.

Yekti Lingga Dinata. (2013) Perbedaan Pengaruh Latihan Front Cone Hops Dan Latihan Zig-Zag Drill Terhadap Peningkatan Power Otot Tungkai. Journal Of Sport Sciences And Fitness Jurusan Ilmu Keolahragaan, Fakultas Ilmu Keolahragaan, Universitas Negeri Semarang. 